\title{
Oxidative and DNA Damage Potential of Colemanite on Zebrafish: Brain, Liver and Blood
}

\author{
Gonca Alak ${ }^{1, *}$, Veysel Parlak ${ }^{1}$, Arzu Ucar ${ }^{1}$, Aslı Cilingir Yeltekin ${ }^{2}$, Fatma Betul \\ Ozgeris $^{3}$, Ozge Caglar ${ }^{4}$, Muhammed Atamanalp ${ }^{1}$, Hasan Turkez ${ }^{5}$
}

\author{
1Department of Aquaculture, Faculty of Fisheries, Atatürk University, TR-25030 Erzurum, Turkey. \\ 2Department of Chemistry, Faculty of Science, University of Yuzuncu YIl, TR-65080, Van, Turkey. \\ ${ }^{3}$ Department of Nutrition and Dietetics, Faculty of Health Sciences, Atatürk University, TR-25030 Erzurum, Turkey. \\ ${ }^{4}$ Department of Molecular Biology and Genetics, Faculty of Science, Erzurum Technical University, TR-25240 Erzurum, Turkey. \\ ${ }^{5}$ Department of Medical Biology, Faculty of Medicine, Ataturk University, TR-25030 Erzurum, Turkey.
}

\section{Article History}

Received 21 November 2019

Accepted 11 March 2020

First Online 06 April 2020

\section{Corresponding Author \\ Tel.: +904422312178 \\ E-mail: galak@atauni.edu.tr}

\section{Keywords}

Colemanite

Boron compounds

Zebrafish

Brain

Liver

Micronucleus assay

Blood

Oxidative stress

DNA damage

\begin{abstract}
Recently, boron has been used in animal feeding due to its significant biological roles. In this study, the action mechanism of colemanite (COL), a commercially important borate mineral, was aimed to investigate via evaluating parameters related to oxidative alterations on the brain, liver and blood tissues of zebrafish. For this purpose, zebrafish were exposed to different doses of $\operatorname{COL}(5,10$ and $20 \mathrm{mg} / \mathrm{L})$ in a static test apparatus for 96 hours. Multiple biochemical analysis including determination of DNA damage (8-OHdG), apoptosis (Caspase-3), superoxide dismutase (SOD), catalase (CAT), glutathione peroxidase (GPX), myeloperoxidase (MPO), paraoxonase (PON), arylesterase (AR) and lipid peroxidation (MDA) levels were performed in brain and liver tissues for assessing oxidative responses. In addition to micronucleus (MN) assay was performed in obtained blood tissues. The results indicated that low doses of $\mathrm{COL}$ supported antioxidant system and did not lead to oxidative stress in zebrafish brain and liver. Again, our results showed colemanite did not cause DNA damage or apoptosis at all tested concentrations. Besides the statistically insignificant changes $(\mathrm{P}>0.05)$ of $\mathrm{MN}$ rates of erythrocytes between the control and experimental groups revealed the non-genotoxic feature of $\mathrm{COL}$ on zebrafish. In conclusion, boron compounds especially $\mathrm{COL}$ can be used safely and provide positive impacts on aquatic environments.
\end{abstract}

\section{Introduction}

Boron is an element with the atomic number 5 , which is in the first place in the $3 \mathrm{~A}$ group on the periodic table, indicated by the symbol "B". Boron has compounds with calcium, magnesium and sodium elements, and several commercially important types; borax (BX) ( $\left.\mathrm{Na}_{2} \mathrm{~B}_{4} \mathrm{O}_{7} \cdot 10 \mathrm{H}_{2} \mathrm{O}\right)$, colemanite (COL) $\left(\mathrm{Ca}_{2} \mathrm{~B}_{6} \mathrm{O}_{11} .5 \mathrm{H}_{2} \mathrm{O}\right)$ and ulexite (UX) $\left(\mathrm{NaCaB}_{5} \mathrm{O}_{9} .8 \mathrm{H}_{2} \mathrm{O}\right)$.
These compounds are also known as natural borates. The usage areas of boron compounds are quite high. In recent years, the biological importance of boron element has been understood and clinical experimental studies have been started to investigate its effects on health. This mineral, which has serious reserves in our country, has widespread uses (glass, ceramics, cleaning, whitening, cosmetics, metallurgy, nuclear, computer, aircraft industry, energy industry, 
agriculture and health) (Helvacl, 2003). Borax mineral is effective on hormone and lipid metabolism as well as free radicals of many enzymes (Comba, Oto, Mis, Özdemir, \& Comba 2016; Acaroz et al., 2019). One of the most common boron minerals, colemanite (COL), is a monoclinic crystalline calcium borate mineral with chemical formula $2 \mathrm{CaO} \cdot 3 \mathrm{~B}_{2} \mathrm{O}_{3} \cdot 5 \mathrm{H}_{2} \mathrm{O}$ (Kızılca \& Copur, 2015). Boron minerals are effective in activity of many enzymes, as well as hormone and lipid metabolism (Comba et al., 2016). Although their action mechanisms are not clear, it has been demonstrated that borates are not metabolized and control the damage of the organism by altering the oxidative stress parameters (Pawa \& Ali, 2006; Acar, İnanan, Zemheri, Kesbiç, \& Yılmaz, 2018; Alak et al. 2018; Alak et al., 2019a; 2019b;2019c). Boron compounds exhibit important biological roles in the development of arthritis, plasma lipid profiles, brain function, mineral (potassium (K), calcium (Ca)) and vitamin (vitamin D) metabolism and hormone (Devirian \& Volpe, 2003; Colak et al., 2011; Ince, Kucukkurt, Acaroz, Arslan-Acaroz, \& Varol, 2019). Borates have also been reported to have protective effects against many diseases such as cancer and neurodegenerative diseases (Gallardo-Williams, Maronpot, Wine, Brunssen, \& Chapin, 2003; Barranco \& Eckhert 2006). In addition, boron/borax in animal organisms has been reported to support the tissue antioxidant defense system by an unknown mechanism via affecting oxidative metabolism (Alak et al., 2018, 2019a; 2019b; 2019c).

Reactive oxygen species (ROS) are formed during normal metabolism in a healthy organism. However, in some cases involving inflammation, drugs, exogenous sources and radiation exposure cause increases of ROS production. As a result, changes in the ROS signal transduction pathway lead to oxidative damages on both lipids and proteins (Ciftci, 2017; Parlak, 2018). The hydroxyl radical and peroxynitrite are particularly damaging to cell membranes and lipoproteins. It initiates chemical chain reactions that cause the formation of malondialdehyde (MDA), which has cytotoxic and mutagenic nature. MDA is formed as a result of oxidative damage and reacted with bases in DNA structure and exhibits mutagenic properties. Endogenous and exogenous antioxidants protect cells from ROS-induced damage in long and short terms via neutralizing or inhibiting the effect by ROS (Borek, Ong, Mason, Donahue \& Biaglow, 1986). However, when ROS is produced excessively or there is a significant decrease in antioxidant defense, the antioxidant defense system is suppressed and oxidative stress occurs. This oxidantantioxidant balance in the organism depends on many factors. These are endogenous and exogenous factors that usually act together (Rahman, 2007).

To our best knowledge, the effects of COL exposure to aquatic organisms have not evaluated yet. Therefore, in this research the use of $\mathrm{COL}$ in fish and its possible protective mechanism considering oxidative stress response were investigated for the first time.

\section{Material and Methods}

\section{Fish Material}

Adult zebrafish (28-32 mm length, $0.40 \pm 0.03 \mathrm{~g}$ weight) were obtained from Atatürk University, Fisheries Faculty (Erzurum, Turkey). Colemanite (COL) applications were performed on the fish whose acclimation was completed in Atatürk University, Faculty of Fisheries, Zebrafish Research and Toxicology Trial Unit.

\section{Colemanite}

Colemanite (COL) $\left(\mathrm{CaB}_{3} \mathrm{O}_{4}(\mathrm{OH})_{3} \mathrm{H}_{2} \mathrm{O}\right.$; Cas no. 131833-8, purity 99.8\%) was obtained from Eti Mine Works (Ankara, Turkey) and the tested concentrations were determined according to the previous study by Rowe, Bouzan, Nabili, \& Eckhert (1998).

\section{Trial Plan and Application of Chemical}

The trial plan was composed according the static test rules in four replications (control $0 \mathrm{mg} / \mathrm{l}$, and experimental groups that exposed to 5,10 and $20 \mathrm{mg} / \mathrm{L}$ of COL. 288 zebrafish were placed in trial mediums randomly and each treatment groups had 24 zebrafish (three replicates). Zebrafish were treated for 96 hours and enzyme activities (SOD, CAT, GPx, PON, and AR) and MPO, MDA, 8-OHdG and Caspase-3 levels were analyzed in obtained zebrafish brain and liver tissues. In addition, $\mathrm{MN}$ assay was performed in blood samples taken at the end of the trial period.

\section{Determination of Enzyme Activities and Lipid Peroxidation (MDA) Level}

\section{Homogenate Preparation}

All group's fish were anesthetized in ice-cold water and subsequently sacrificed (Liu, Wang, Wei, Zhang, Xu, \& Dai, 2008). After collecting six fish's tissues (brain and liver) from each treated and control groups (Yan, Wang, Zhu, Chen, \& Wang, 2015) homogenized in phosphate buffer (0.1M phosphate buffer $\left.\mathrm{KH}_{2} \mathrm{PO}_{4}, \mathrm{pH} 7.4\right)$ and centrifuged at 1300 rpm for 30 minutes (Yan et al. 2015; Alak et al. 2017a, 2017b, 2019c). Four homogenates were prepared at each group. Protein concentration was determined spectrophotometric at $595 \mathrm{~nm}$ according to the Bradford method (Bradford 1976). These obtained homogenates (SOD, CAT, GPx, MPO, PON, AR, MDA, Caspase-3 and $8-\mathrm{OHdG}$ ) were used in analysis.

\section{Measurement of Superoxide Dismutase (SOD) Enzyme Activity}

The color change observed as a result of the reaction of superoxide radicals formed by xanthine oxidase enzymatic reaction with NBT was measured by 
spectrophotometer at $560 \mathrm{~nm}$ (Sun, Oberley, \& Li, 1988).

\section{Measurement of Catalase (CAT) Activity}

The method of Aebi (1974) was taken into consideration and the reaction of hydrogen peroxide $\left(\mathrm{H}_{2} \mathrm{O}_{2}\right)$ degradation by catalase enzyme was measured with the absorbance reduction rate determined at 240 $\mathrm{nm}$.

\section{Measurement of Glutathione Peroxidase (GPx) Activity}

GPx activity was determined by measuring the difference in decrease of absorbance during the oxidation of NADPH to NADP ${ }^{+}$(Beutler 1984).

\section{Measurement of Myeloperoxidase (MPO) Activity}

It is based on the kinetic measurement of the absorbance of the yellowish-orange colored complex resulting from the oxidation of o-dianisidine with MPO in the presence of hydrogen peroxide at the wavelength of $460 \mathrm{~nm}$ (Bradley, Priebat, Christensen, \& Rothstein, 1982).

\section{Measurement of Paraoxonase (PON) Activity}

Spectrophotometric absorbance change (in unit time) of P-nitrophenol formed by paraoxone hydrolysis was considered at $37^{\circ} \mathrm{C}$ and at $412 \mathrm{~nm}$ (Gülcü \& Gürsü, 2003).

\section{Measurement of Arylesterase (AR) Activity}

ARE activity was determined by measuring the absorbance of phenol formed at $270 \mathrm{~nm}$ with the method using phenyl acetate as substrate (Gülcü \& Gürsü, 2003).

\section{Measurement of Lipid Peroxidation (MDA)}

The level of lipid peroxidation was obtained by determining the level of malondialdehyde (MDA), a product of lipid peroxidation (Alak et al., 2019d).

\section{Determination of Apoptosis (Caspase-3) Level}

The level of Caspase- 3 in brain and liver tissues was determined with the help of a commercial kit (Fish (CASP3) ELISA Kit (Catalog No: 201-00-0031) (SunRed). According to prospectuse, the prospectus of a commercial kit had been considered. Caspase-3 standard was prepared by diluting with Standard diluent and left in Microelisa Strip Plate wells as $50 \mu$ l. One well was chosen as blank and the remaining wells were placed in $40 \mu \mathrm{l}$ of samples. $50 \mu \mathrm{l} \mathrm{Str-HRP-Conjugate}$ Reagent was added to each well. $10 \mu$ l Biotin- (CASP3) $\mathrm{Ab}$ was added to the sample and the platen was covered. The plate was incubated in the plate shaker at $37^{\circ} \mathrm{C}$ for 1 hour. Plate wells were washed with $30 \mathrm{X}$ Wash Buffer $(350 \mu \mathrm{l}$ per well) and diluted 30 times with distilled water, waited for 1-2 minutes then this was repeated 5 times. After washing, $50 \mu$ of Chromogen Solution A and $50 \mu$ l of Chromogen Solution B were added to each well and incubated for $10 \mathrm{~min}$ in the plate shaker at $37^{\circ} \mathrm{C}$ in the dark. As a result of the incubation, $50 \mu \mathrm{l}$ Stop Solution was added to the plate wells and the measurement was made in ELISA (Plate Reader) device with $450 \mathrm{~nm}$ absorbance within 10 minutes (Alak et al. 2018).

\section{Determination of DNA damage (8-OHdG) Level}

The level of 8-OHdG in brain and liver tissues was determined with the help of a commercial kit (Fish (8OHdG) Catalog No: 201-00-0041 / SunRed). In this method, standards prepared for $8-0 H d G$ are added in Microelisa Strip Plate, as $50 \mu \mathrm{l}$. It is selected blank in one well and then $40 \mu \mathrm{l}$ of samples are added to the other wells. $50 \mu \mathrm{l}$ of Str-HRP-Conjugate Reagent is added to each well then only $10 \mu$ l of Biotin- (8-OHdG) Ab is added to the sample and the plate is covered. The plate is incubated at $37^{\circ} \mathrm{C}$ in the Plate Shaker for 1 hour. Plate wells are washed 5 times with 30X Wash Buffer (300 $\mu$ l / well) diluted 30 times with distilled water, after waited 1-2 minutes. After washing, $50 \mu \mathrm{l}$ of Chromogen Solution A was added and then adding $50 \mu \mathrm{l}$ of Chromogen Solution $B$ to each tube and incubate for 10 minutes in the Plate Shaker at $37^{\circ} \mathrm{C}$ in the dark. As a result of incubation, $50 \mu \mathrm{l}$ Stop Solution is added to the plate wells and the measurement was done in ELISA (Plate Reader) device with an absorbance of $450 \mathrm{~nm}$ within 10 minutes (Alak et al. 2018).

\section{Micronucleus (MN) Assay in Zebrafish Erythrocytes}

MN test was performed with blood of 8 fish sampled from each of the treatment and control groups according to chance. For MN test, one drop of blood from each sample in groups was immediately smeared on clean glass slides, then glass slides were allowed to dry (Baršiene, Dedonyte, Rybakovas, Andreikenait \& Andersen, 2006). The slides fixed with methanol for 10 min, then stained with $5 \%$ Giemsa (Merck, Germany) for $30 \mathrm{~min}$. In zebrafish erythrocytes, the frequencies of $\mathrm{MN}$ were calculated by counting MN/1000 cells per fish at 100X magnification.

\section{Statistical Analyses}

All data are given with standard deviation and mean values. The differences among the groups were determined by one-way (ANOVA) variance analysis and then evaluated by Duncan's test via SPSS program $(P<0.05)$. 


\section{Results}

The potential regulatory effect of $\mathrm{COL}$ and the reference range for fish were investigated in three different categories and multiple biochemical analyzes in 96-hour administration of adult zebrafish brain and liver tissue.

\section{Enzyme Activities and Lipid Peroxidation Level}

The alterations in antioxidant enzyme activities were observed in brain and liver tissues after the administration of COL (5 10 and $20 \mathrm{mg} / \mathrm{l}$ ) to zebrafish adults (after 96 hours) $(\mathrm{P}<0.05)$. According to the data obtained from the Table1, brain tissue and Table 2 liver tissue results, it was found that high dose $(20 \mathrm{mg})$ colemanite administration significantly increased the MDA level for both tissues compared to the control. This situation has been interpreted as triggering oxidative stress and a similar situation had been observed in liver tissue. In the liver tissue findings, it was found that cleomonite treatment as $5 \mathrm{mg}$ / I gave statistically similar and close results in some antioxidant enzyme activities.

It was determined that high concentration application $(20 \mathrm{mg} / \mathrm{I})$ of $\mathrm{COL}$ in both tissues has an inhibitory effect compared to control in SOD, CAT, GPx, PON and AR enzyme activites (Tables 1 and 2).

\section{DNA Damage and Apoptosis Level}

After the administration of $\mathrm{COL}$ to zebrafish adults (at the end of 96th hour), significant alterations in 8OHdG levels in brain tissues were observed among the groups $(\mathrm{P}<0.05)$. The low doses of $\mathrm{COL}(5,10$ and 20 $\mathrm{mg} / \mathrm{ll}$ led to lower levels of 8-OHdG in comparison to control group (Figure 1). Similar situation was observed in Caspase- 3 activity and the difference between the groups was statistically significant $(P<0.05)$ (Figure 2$)$.

\section{Micronucleus Test in Zebrafish Erythrocytes}

MN rates that observed in each experimental groups are shown in Figures 3 and 4. All tested COL doses did not alter the $\mathrm{MN}$ rates as compared to the control fish. The insignificant alterations $(P>0.05)$ among the control and $\mathrm{MN}$ treatment groups revealed a nongenotoxic nature of COL on zebrafish blood.

\section{Discussion}

\section{Enzyme Activities and Lipid Peroxidation Level}

In our study, it was determined that low dose of COL supported antioxidant system. In addition, low concentrations of $\mathrm{COL}$ yielded lower results in brain MDA levels as compared to control group. Likewise, the determined enzyme activities for these groups ( 5 and 10 $\mathrm{mg} / \mathrm{l})$ supported our findings that oxidative stress did not occur due to $\mathrm{COL}$ exposure. As supporting the present findings, Türkez, Geyikoğlu, Tatar, Keleş, \& Özkan, (2007) reported that boron compounds including boric acid, borax, ulexite and $\mathrm{COL}$ supported antioxidant enzyme activities and showed non-genotoxic damage potentials. In this line, the result of study by Geyikoğlu \& Türkez (2008) also supported our findings which revealed that boron compounds increased antioxidant enzyme activities at relatively low concentrations $(<20$ $\mathrm{mg} / \mathrm{l})$ and decrease at high concentrations $(>160 \mathrm{mg} / \mathrm{l})$. In another study, it was reported that the antioxidant defense system of the rats was strengthened with oral borax supplementation (Pawa \& Ali, 2006). Similarly, Nielsen (1994) reported that boron led to increases of SOD levels. In this study, increased SOD activities could be effective by increasing antioxidant capacity (Hunt 1998; Alak et al., 2013). When the results obtained from this study were examined, it was found that borax (a borate like $\mathrm{COL}$ ) supported antioxidant activity due to increased SOD activity. In addition, the increase in GPx activity in brain tissue is thought to be an adaptive response to boron intake (Mohora, Boghianu, Muscurel, Dute, \& Dumitrache, 2002; Alak et al. 2019d). Some researchers had reported that the effects of boron derivatives on CAT enzyme may differ even in different tissues of animals (Verbitskaya, 1975; Hunt, Herbel, \& Idso, 1993). Paraoxonase enzymes exhibit a highly athero-protective effect by hydrolyzing lipid hydroperoxides and prevent oxidative damage formation (Draganov \& La Du 2004). Our study is the first report in aquaculture that $\mathrm{COL}$ gives higher results in enzyme activities as compared to control, statistically these increases are important and at the same time, $\mathrm{COL}$ promotes antioxidant enzyme activities. Boron compounds are known to have negative effects on GPx at lower levels than those associated with other enzymes. At this point, a clear dose-response relationship between boron compounds and this enzyme can be established. It has been reported that selenium has significant roles on the activity of this enzyme (Al-Saleh \& Al-Doush, 1997; Turkez et al. 2007). However, although we know that boron compounds do not only interact with selenium, we cannot say that the effects on the antioxidant enzymes of boron compounds are solely caused by selenium. The protective effect of $\mathrm{COL}$ was investigated and positive impact were observed in this study. As known, the increase in ROS causes a rise in lipid peroxidation and MDA levels. Free radicals affect lipids, proteins, carbohydrates and important cell structures. Lipid peroxides rapidly decompose to form reactive carbon compounds. One of the important structures that occur is MDA and the increasing of MDA has been accepted as a physiologically important indicator of oxidative stress (Nielsen et al., 1997; Alak et al., 2017a; 2017b; 2019d). MDA level was found to be lower in low and medium dose COL applied groups than in high dose group and it has been determined that this situation is parallel with previous studies that performed on different organisms or with different borate compounds (Ince, Kucukkurt, 
Table 1. Alteration in oxidative parameters after exposure to COL on zebrafish (Danio rerio) brain (Mean \pm SD)

\begin{tabular}{lccccccc}
\hline Treatments & $\begin{array}{c}\text { CAT } \\
(\mathrm{EU} / \mathrm{mg})\end{array}$ & $\begin{array}{c}\text { SOD } \\
(\mathrm{EU} / \mathrm{mg})\end{array}$ & $\begin{array}{c}\text { GPx } \\
(\mathrm{EU} / \mathrm{mg})\end{array}$ & $\begin{array}{c}\text { PON } \\
(\mathrm{U} / \mathrm{ml})\end{array}$ & $\begin{array}{c}\text { AR } \\
(\mathrm{U} / \mathrm{ml})\end{array}$ & $\begin{array}{c}\text { MPO } \\
(\mathrm{U} / \mathrm{ml})\end{array}$ & $\begin{array}{c}\text { MDA } \\
(\mathrm{nmol} / \mathrm{protein})\end{array}$ \\
\hline Control & $0.734 \pm 0.44^{\mathrm{a}}$ & $1.069 \pm 0.36^{\mathrm{a}}$ & $1.175 \pm 0.25^{\mathrm{a}}$ & $116.310 \pm 7.35^{\mathrm{a}}$ & $101.221 \pm 7.84^{\mathrm{a}}$ & $65.344 \pm 18.29^{\mathrm{c}}$ & $0.149 \pm 0.04^{\mathrm{c}}$ \\
$5 \mathrm{mg} / \mathrm{l}$ & $0.459 \pm 0.19^{\mathrm{b}}$ & $0.735 \pm 0.14^{\mathrm{b}}$ & $0.626 \pm 0.108^{\mathrm{b}}$ & $97.281 \pm 12.51^{\mathrm{b}}$ & $90.862 \pm 4.34^{\mathrm{ab}}$ & $138.918 \pm 37.60^{\mathrm{b}}$ & $0.249 \pm 0.08^{\mathrm{bc}}$ \\
$10 \mathrm{mg} / \mathrm{l}$ & $0.344 \pm 0.13 \mathrm{~b}^{\mathrm{c}}$ & $0.686 \pm 0.15^{\mathrm{b}}$ & $0.592 \pm 0.07^{\mathrm{bc}}$ & $87.956 \pm 6.98^{\mathrm{b}}$ & $79.651 \pm 12.30^{\mathrm{bc}}$ & $142.488 \pm 22.64^{\mathrm{b}}$ & $0.401 \pm 0.14^{\mathrm{b}}$ \\
$20 \mathrm{mg} / \mathrm{l}$ & $0.243 \pm 0.10^{\mathrm{c}}$ & $0.506 \pm 0.19^{\mathrm{b}}$ & $0.413 \pm 0.17^{\mathrm{c}}$ & $36.753 \pm 6.62^{\mathrm{c}}$ & $70.796 \pm 12.78^{\mathrm{c}}$ & $181.469 \pm 23.21^{\mathrm{a}}$ & $0.735 \pm 0.21^{\mathrm{a}}$ \\
\hline
\end{tabular}

Lowercase superscripts (a, b, c, d) indicate significant differences among same column within each experimental treatment group, $P<0.05$

Table 2. Alteration in oxidative parameters after exposure to COL on zebrafish (Danio rerio) liver (Mean \pm SD)

\begin{tabular}{lccccccc}
\hline Treatments & $\begin{array}{c}\text { CAT } \\
(\mathrm{EU} / \mathrm{mg})\end{array}$ & $\begin{array}{c}\text { SOD } \\
(\mathrm{EU} / \mathrm{mg})\end{array}$ & $\begin{array}{c}\text { GPx } \\
(\mathrm{EU} / \mathrm{mg})\end{array}$ & $\begin{array}{c}\text { PON } \\
(\mathrm{U} / \mathrm{ml})\end{array}$ & $\begin{array}{c}\text { AR } \\
(\mathrm{U} / \mathrm{ml})\end{array}$ & $\begin{array}{c}\text { MPO } \\
(\mathrm{U} / \mathrm{ml})\end{array}$ & $\begin{array}{c}\text { MDA } \\
\text { (nmol/protein) }\end{array}$ \\
\hline Control & $0.658 \pm 0.35^{\mathrm{a}}$ & $1.138 \pm 0.12^{\mathrm{a}}$ & $0.871 \pm 0.13^{\mathrm{a}}$ & $127.679 \pm 22.48^{\mathrm{a}}$ & $99.590 \pm 9.80^{\mathrm{a}}$ & $6.687 \pm 2.02^{\mathrm{b}}$ & $0.318 \pm 0.02^{\mathrm{b}}$ \\
$5 \mathrm{mg} / \mathrm{l}$ & $0.502 \pm 0.20^{\mathrm{ab}}$ & $1.155 \pm 0.10^{\mathrm{a}}$ & $0.532 \pm 0.10^{\mathrm{b}}$ & $67.224 \pm 14.56^{\mathrm{b}}$ & $97.750 \pm 6.03^{\mathrm{a}}$ & $12.899 \pm 7.84^{\mathrm{b}}$ & $0.241 \pm 0.09^{\mathrm{b}}$ \\
$10 \mathrm{mg} / \mathrm{l}$ & $0.399 \pm 0.18^{\mathrm{b}}$ & $0.894 \pm 0.16^{\mathrm{b}}$ & $0.434 \pm 0.14^{\mathrm{b}}$ & $50.285 \pm 13.09^{\mathrm{c}}$ & $83.960 \pm 8.00^{\mathrm{b}}$ & $18.306 \pm 14.09^{\mathrm{ab}}$ & $0.418 \pm 0.03^{\mathrm{ab}}$ \\
$20 \mathrm{mg} / \mathrm{l}$ & $0.380 \pm 0.15^{\mathrm{b}}$ & $0.654 \pm 0.09^{\mathrm{c}}$ & $0.230 \pm 0.06^{\mathrm{c}}$ & $19.104 \pm 7.07^{\mathrm{d}}$ & $79.380 \pm 7.46^{\mathrm{b}}$ & $29.449 \pm 20.53^{\mathrm{a}}$ & $0.621 \pm 0.02^{\mathrm{a}}$ \\
\hline
\end{tabular}

Lowercase superscripts (a, b, c, d) indicate significant differences among same column within each experimental treatment group, $\mathrm{P}<0.05$

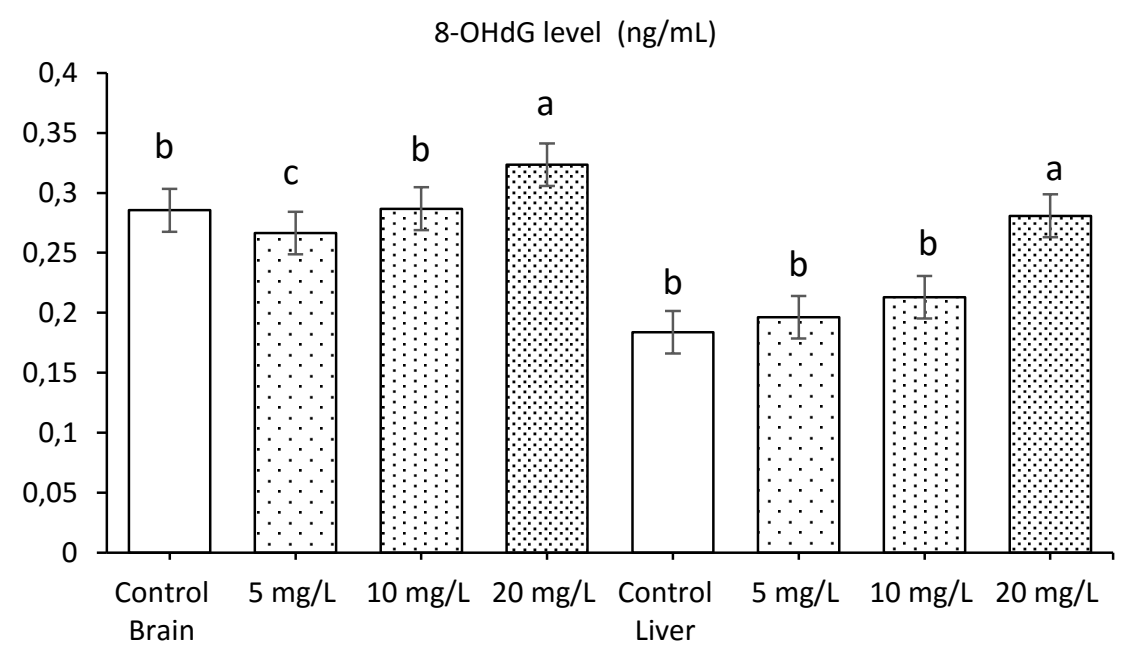

Figure 1. The effect of $\mathrm{COL}$ on 8-OHdG level in zebrafish (Danio rerio) brain and liver. Lowercase superscripts (a, b, c) indicate significant statistical differences among the experimental groups, $\mathrm{P}<0.05$.

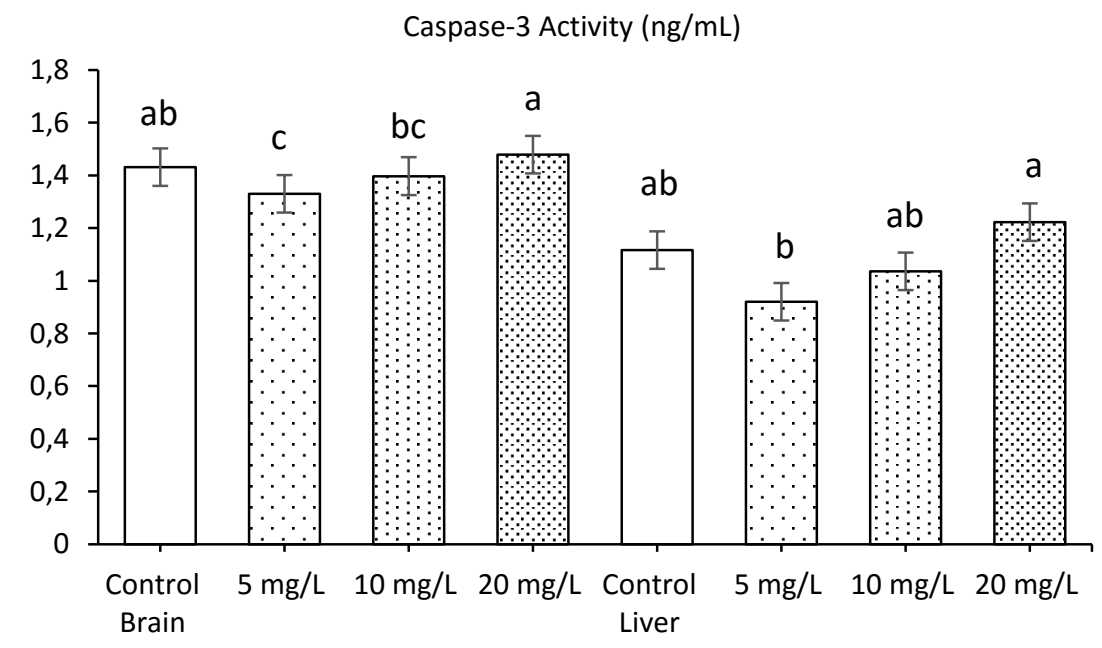

Figure 2. The effect of COL on Caspase-3 activity in zebrafish (Danio rerio) brain and liver. Lowercase superscripts (a, b, c, d) indicate significant statistical differences among the experimental treatment groups, $\mathrm{P}<0.05$. 


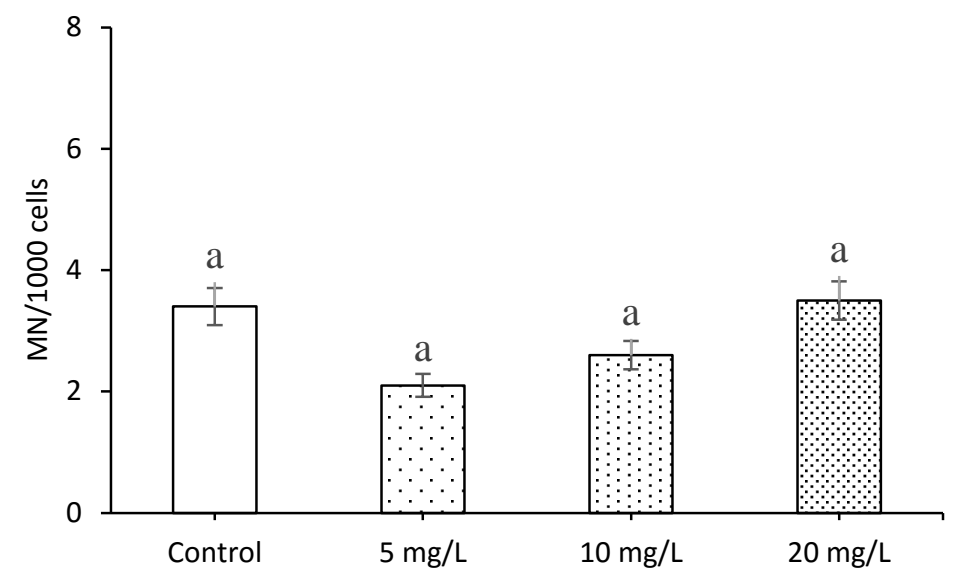

Figure 3. Micronucleus formation rates in Danio rerio erythrocytes after treatment with different colemanite doses. Values are presented as mean \pm SD of four repetition, $\mathrm{P}<0.05$.

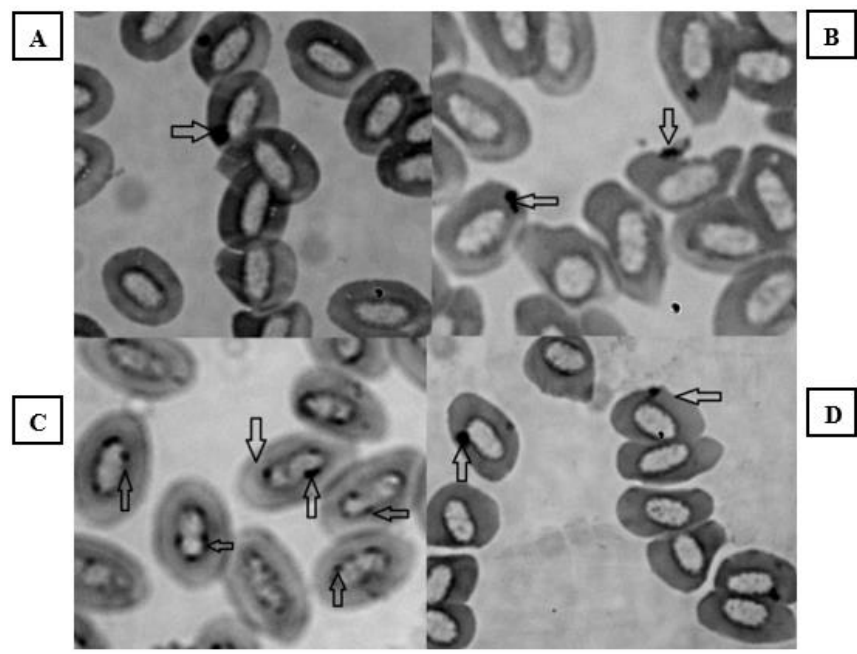

Figure 4. The sample micronucleus images of the experimental groups. A. $5 \mathrm{mg} / \mathrm{L}$ of COL; B. $10 \mathrm{mg} / \mathrm{L}$ of COL; C. $20 \mathrm{mg} / \mathrm{L}$ of COL; D. Control (Arrows show the MN formation).

Cigerci, Fidan, \& Eryavuz, 2010; Alak et al., 2018; 2019a; 2019b; 2019c). Boron had been reported to create protective effects by both blocking LPO and increasing antioxidant defense system activity (Küçükkurt, Acaröz, Demirel, İnce, \& Eryavuz, 2017). Reduction of MDA modulation and strengthening of antioxidant system are thought to be effective in PON activation in COL treated groups (Ozdulger et al. 2003; Price, Uras, Banks, \& Ercal,2006; Jasna, Anandbabu, Bharathi, \& Angayarkanni, 2014). The results of arylesterase enzyme activity in brain and liver tissue in all COL administrated groups are consistent with paraoxonase activity results and may have emerged with similar mechanisms.

Although the biochemical function of boron is not yet fully known, it has been reported to act as an indirect proton donor, which has a specific effect on cell membrane structure and function (Barr, Barton, \& Schull, 1996). Accordingly, it has been reported that boron compounds (boric acid and borax) may affect oxidative phosphorylation metabolism in mitochondria by increasing CAMP levels and inhibit hydrolytic enzyme activities (Hall et al., 1980). In addition, it was reported that increases in cAMP levels may increase antioxidant enzyme activities (Sugino, Karube-Harada, Sakata, Takiguchi, \& Kato, 2002). Again, in another study, boron was reported to prevent oxidative damage, by increasing glutathione and analogues or other neutralizing agents (Turkez, Geyikoglu, \& Colak, 2011).

\section{DNA Damage Grade and Apoptosis Level}

Alterations in enzyme activity and DNA damage are widely used as important biomarkers to reduce the geno-toxicity and oxidative stress of natural and / or man-made chemical materials (Celikezen, Toğar, Özgeriş, Izgi, \& Türkez, 2016). Increased levels of MDA and MPO obtained at the highest dose of COL $(20 \mathrm{mg} / \mathrm{l})$ indicated the occurance of oxidative stress. The increased 8-OHdG levels are confirmed by MDA increase. Diffusible MDA reacts with the nitrogen bases of the DNA (Frank, \& Massaro, 1980; Freeman, \& Crapo, 1982; Niki, Yoshida, Saito \& Noguchi, 2005). It is thought 
that, boron containing compounds exhibit modulating effect on 8-OHdG levels as determined in applications with low and medium doses of COL (5 and $10 \mathrm{mg} / \mathrm{l}$ ) (Alak et al. 2018).

The last step in the mechanism of apoptotic damage is activation of caspase 3. Caspase 3 is induced by some caspase genes such as CASP1, CASP8, CASP9 and CASP12. In parallel with this information, the highest dose of $\mathrm{COL}$ increased the caspase 3 level. The main issue that needs to be clarified here is to what extent the caspase 3 is activated by the application of COL.

The increase in caspase 3 in brain tissues with high dose $(20 \mathrm{mg} / \mathrm{l})$ is also parallel to the decrease in enzymes activity in the same group. It can be said that this situation causes an increase in apoptotic cells due to disruption of enzyme balance in the body and change of apoptosis pathway. These data were supported by high levels of MDA in tissues as well as 8-OHgD level and MPO activity.

As in the present study, boron containing (ulexite, colemanite, borax, etc.) agents used in therapy might induce apoptosis that activates caspase 3 and suppressed certain mechanisms (Hazman, Bozkurt, Fidan, Uysal, \& Çelik, 2018). Apoptosis suppressing by borax has also been reported in a small number of aquaculture studies investigating the anti-apoptotic effect of borax on toxicity models (Alak et al. 2018; 2019a; 2019b; 2019c). Boron supplementation was found to reduce tissue antioxidant defense but also geno-toxicity (Yazıcı, Aksit, Korkut, Sunay, \& Çelik, 2014). In our study, it was determined that COL, in low doses, had no negative effect on apoptosis and DNA damage. We can evaluate this situation as strengthening tissue antioxidant defense with COL supplementation. Similarly, Khaliq et al. (2018) reported that low doses of boron regulate cellular apoptosis by overcoming oxidative stress. Similar to our results, it had been reported that $10 \mathrm{mg} / \mathrm{L}$ boron supplement inhibits apoptosis in a previous study (Jin et al., 2017).

\section{Micronucleus in Zebrafish Erythrocytes}

There is no performed investigation on evaluation of geno-toxic damage potential by $\mathrm{COL}$ on aquatic organisms. Therefore, in this study, geno-toxic evaluations were performed by using $\mathrm{MN}$ assay to provide more reliable information on $\mathrm{COL}$. The obtained data showed that there was no significant increase in $\mathrm{MN}$ rates in erythrocytes exposed to $\mathrm{COL}$ as compared to control values. These findings are consistent with previous evaluations (Celikezen, Turkez, Togar, \& Izgi, 2014; Celikezen et al., 2016). At the end of the study, it was determined that $\mathrm{COL}$ had no geno-toxic damage potential. These results are in line with the previous findings showing that boron compounds (such as borax, boric acid) are non-genotoxic in cultured human blood cells (Turkez et al., 2007, Turkez, Tatar, Hacimuftuoglu, \& Ozdemir, 2010; Geyikoglu \& Turkez 2008; Turkez,
2008; Celikezen et al., 2014; 2016). Gülsoy, Yavas, \& Mutlu (2018), was expressed in their study; the same type of borax and boric acid compounds may differ significantly depending on the time (increase in toxicity at 24 hours and decrease in 48, 72 and 96 hours). At 96 hours, this rate was still higher than the negative control level at all doses administered. They attributed the determined reductions to the repair of cytoprotective and tolerance mechanisms or damaged DNA in the cell.

These previous data and the present findings clearly revealed that $\mathrm{COL}$ and other boron compounds have no DNA damaging action or genotoxic damage potentials in both in vitro and in vivo conditions. Gulsoy et al. (2018) were assumed that boron compounds administered in vitro are not sufficient to show their genotoxic potential separately in short periods (1-2 hours) and low concentrations (1.25-5mg / L).

\section{Conclusion}

This study clearly demonstrated that COL, one of the most important commercial boron compounds, promoted antioxidant capacity at 5 and $10 \mathrm{mg} / \mathrm{l}$ concentrations in fish liver. Our results also showed that low concentrations of $\mathrm{COL}$ did not cause to oxidative stress, DNA damage and apoptosis generations in the brain and liver. In addition, low doses of COL (5 and 10 $\mathrm{mg} / \mathrm{l})$ were found to be more effective in preventing oxidative stress than higher dose $(20 \mathrm{mg} / \mathrm{l})$. Finally, we revealed that $\mathrm{COL}$ did not induce geno-toxicity zebrafish, there was no significant increase in $\mathrm{MN}$ frequency, oxidative stress, apoptosis and DNA damage levels.

As a conclusion, boron compounds especially $\mathrm{COL}$ can be used safely, but it would be beneficial to consider the cellular damages that are likely to develop due to oxidative stress at its excessive doses. The findings may be useful to explain possible side effects of boron compounds at excessive amounts or their effectiveness in treatment protocols.

\section{References}

Acar, Ü., İnanan, B. E., Zemheri, F., Kesbiç, O. S., \& Yılmaz, S. (2018). Acute exposure to boron in Nile tilapia (Oreochromis niloticus): Median-lethal concentration (LC50), blood parameters, DNA fragmentation of blood and sperm cells. Chemosphere, 213, 345-350. Doi: 10.1016/j.chemosphere.2018.09.063

Acaroz, U., Ince, S., Arslan-Acaroz, D., Gurler, Z., Demirel, H. H., Kucukkurt, I., Eryavuz, A., Kara, R., Varol, N., \& Zhu, K. (2019). Bisphenol-A induced oxidative stress, inflammatory gene expression, and metabolic and histopathological changes in male Wistar albino rats: protective role of boron. Toxicology Research, 8(2), 262269. Doi: $10.1039 / \mathrm{c} 8 \mathrm{tx} 00312 \mathrm{~b}$

Aebi, H., (1974). Catalase. In: Methods of Enzymatic Analysis, Academic Press, New York, Bergmeyer, HU, USA, pp.673-678.

Alak, G., Atamanalp, M., Topal, A., Arslan, H., Oruç, E., \& Altun, S. (2013). Histopathological and biochemical effects of humic acid against cadmium toxicity in brown trout gills 
and muscles. Turkish Journal of Fisheries and Aquatic Sciences, 13(2), 315-320. DOI: 10.4194/1303-2712v13_2_13

Alak, G., Parlak, V., Aslan, M.E., Ucar, A., Atamanalp, M., \&Turkez, H. (2019c). Borax supplementation alleviates hematotoxicity and DNA damage in rainbow trout (Oncorhynchus mykiss) exposed to copper. Biological Trace Element Research, 187(2), 536-542. https://doi.org/10.1007/s12011-018-1399-6

Alak, G., Parlak, V., Yeltekin, A.Ç., Ucar, A., Çomaklı, S., Topal, A., Atamanalp, M., Özkaraca, M., \& Türkez, H.(2019a). The protective effect exerted by dietary borax on toxicity metabolism in rainbow trout (Oncorhynchus mykiss) tissues. Comparative Biochemistry and Physiology Part C: Toxicology \& Pharmacology, 216, 82-92. https://doi.org/10.1016/j.cbpc.2018.10.005

Alak, G., Ucar, A., Çilingir Yeltekin, A., Parlak, V., Nardemir, G., Kızılkaya, M., Taş, I.H., Yılgın, M., Atamanalp, M., Topal, A., Kocaman, M.E., \&Yanık, T. (2019d). Neurophysiological responses in the brain tissues of rainbow trout (Oncorhynchus mykiss) treated with biopesticide. Drug and Chemical Toxicology, 42(2), 203-209. https://doi.org/10.1080/01480545.2018.1526180

Alak, G., Ucar, A., Parlak, V., Yeltekin, A.Ç., Tas, I.H., Ölmez, D., Kocaman, E.M., Yılgın, M., Atamanalp, M., \& Yanık, T. (2017b) Assessment of 8-hydroxy-2-deoxyguanosine activity, gene expression and antioxidant enzyme activity on rainbow trout (Oncorhynchus mykiss) tissue exposed to biopesticide. Comparative Biochemistry and Physiology Part C: Toxicology \& Pharmacology. 203, 5158, https://doi.org/10.1016/j.cbpc.2017.10.007

Alak, G., Ucar, A., Yeltekin, A.Ç., Çomaklı, S., Parlak, V., Taş, I.H., Özkaraca, M., Topal, A., Kirman, E.M., Bolat, i., Atamanalp, M., \& Türkez, H. (2018). Neuroprotective effects of dietary borax in the brain tissue of rainbow trout (Oncorhynchus mykiss) exposed to copper-induced toxicity. Fish Physiology and Biochemistry. 44(5), 14091420. https://doi.org/10.1007/s10695-018-0530-0

Alak, G., Yeltekin, A.Ç., Tas, I.H., Ucar, A., Parlak, V., Topal, A., Kocaman, E.M., \&Atamanalp, M. (2017a). Investigation of 8-OHdG, CYP1A, HSP70 and transcriptional analyses of antioxidant defense system in liver tissues of rainbow trout exposed to eprinomectin. Fish \& Shellfish Immunol. 65, 136-144. https://doi.org/10.1016/j.fsi.2017.04.004

Alak, G., Yeltekin, A.Ç., Ucar, A., Parlak, V., Türkez, H., \& Atamanalp, M. (2019b). Borax alleviates copper-induced renal injury via inhibiting the DNA damage and apoptosis in rainbow trout. Biological Trace Element Research, 191(2): 495-501. https://doi.org/10.1007/s12011-018$1622-5$

Al-Saleh, I.A., \& Al-Doush, I. (1997). Selenium levels in wheat grains grown in Saudi Arabia. Bull. Environ. Contam. Toxicol.59, 590-594.

Barr, R.D., Barton, S.A., \& Schull, W.J. (1996). Boron levels in man: preliminary evidence of genetic regulation and some implications for human biology. Medical hypotheses. 46(3), 286-289.

https://doi.org/10.1016/S0306-9877(96)90257-1

Barranco, W.T., \& Eckhert, C.D. (2006). Cellular changes in boric acid-treated DU-145 prostate cancer cells. Brit J Cancer. 94,884-90.

Baršiene, J., Dedonyte, V., Rybakovas, A., Andreikenait, L., \& Andersen, O.K. (2006). Investigation of micronuclei and other nuclear abnormalities in peripheral blood and kidney of marine fish treated with crude oil. Aquat Toxicol. 78S, S99-S104. https://doi.org/10.1016/j.aquatox.2006.02.022

Beutler, E. (1984). Red Cell Metabolism: A Manual of Biochemical Methods, Second Edn., Grune and Starton, NewYork.

Borek, C., Ong, A., Mason, H., Donahue, L., \& Biaglow, J.E. (1986). Selenium and vitamin E inhibit radiogenic and chemically induced transformation in vitro via different mechanisms. Proc Natl Acad Sci,83, 1490-1494. https://doi.org/10.1073/pnas.83.5.1490

Bradford, M.M. (1976) A rapid and sensitive method for the quantitation of microgram quantities of protein utilizing the principle of protein dye binding. Anal. Biochem 72, 248-254. https://doi.org/10.1016/0003-2697(76)905273

Bradley, P.P., Priebat, D.A., Christensen, R.D., \& Rothstein, G. (1982). Measurement of cutaneous inflammation: estimation of neutrophilcontent with an enzyme marker. J Invest Dermatol. 78, 206-209. https://doi.org/10.1111/1523-1747.ep12506462

Celikezen, F.Ç., Toğar, B., Özgeriş, F.B., Izgi, M.S., \& Türkez, H. (2016). Cytogenetic and oxidative alterations after exposure of cultured human whole blood cells to lithium metaborate dehydrate. Cytotechnology. 68(4), 821-827. Doi 10.1007/s10616-014-9833-x

Celikezen, F.Ç., Turkez, H., Togar, B., \& Izgi, M.S. (2014). DNA damaging and biochemical effects of potassium tetraborate. EXCLI journal. 13, 446.

Çiftçi, N. (2017). The role of oxidative stress in cancer: Could antioxidants fuel the progression of cancer? Ahi Evran Tıp Dergisi, 1(1), 8-13.

Colak, S., Geyikoglu, F., Keles, O.N., Turkez, H., Topal, A., \& Unal, B. (2011). The neuroprotective role of boric acid on aluminum chloride-induced neurotoxicity. Toxicol Ind Health. 27, 700-10. https://doi.org/10.1177/0748233710395349

Comba, B., Oto, G., Mis, L., Özdemir, H., \& Comba, A. (2016). Effects of borax on inflammation, haematological parameters and total oxidant-antioxidant status in rats applied 3-methylcholanthrene. Kafkas Univ Vet Fak Derg., 22 (4), 539-544.Doi: 10.9775/kvfd.2016.15001

Devirian, T.A., \& Volpe, S.L. (2003). The physiological effects of dietary boron.Crit. Rev. Food Sci. Nutr. 43 (2), 219. https://doi.org/10.1080/10408690390826491

Draganov, D.I., \& LaDu, N.B. (2004). Pharmacogenetics of paraoxonases: a brief review. Naunyn-Schmiedeberg's Archives of Pharmacology. 369(1):78-88. Doi 10.1007/s00210-003-0833-1

Frank, L., \& Massaro, D. (1980). Oxygen toxicity. Am J Med. 69(1), 117-126. https://doi.org/10.1016/00029343(80)90509-4

Freeman, B.A., \& Crapo, J.D., (1982). Biology of disease: free radicals and tissue injury. Lab Invest., 47, 412-426.

Gallardo-Williams, M.T., Maronpot, R.R., Wine, R.N., Brunssen, S.H., \& Chapin, R.E. (2003). Inhibition of the enzymatic activity of prostate-specific antigen by boric acid and 3nitrophenyl boronic acid. The Prostate, 54(1), 44-49. https://doi.org/10.1002/pros.10166

Geyikoğlu, F., \& Türkez, H. (2008). Boron compounds reduce vanadium tetraoxide genotoxicity in human lymphocytes. Environ Toxicol Pharmacol 26, 342-347. https://doi.org/10.1016/j.etap.2008.07.002

Gülcü, F., \& Gürsü, M.F. (2003). The standardization of paraoxonase and arylesterase activity measurements. Turkish Journal of Biochemistry. 28 (2), 45-49.

Gülsoy, N., Yavas, C., \& Mutlu, Ö. (2015). Genotoxic effects of boric acid and borax in zebrafish, Danio rerio using 
alkaline comet assay. EXCLI journal, 14, 890. Doi: 10.17179/excli2015-404

Hall, I.H., Starnes, C.O, McPhail, A.T., Wisian-Neilson, P., Das, M.K., Harchelroad Jr, F., \& Spielvogel, B.F. (1980). Antiinflammatory activity of amine cyanoboranes, amine carboxyboranes, and related compounds. Journal of Pharmaceutical Sciences. 69(9), 1025-1029. https://doi.org/10.1002/jps.2600690912

Hazman, Ö., Bozkurt, M.F., Fidan, A.F., Uysal, F.E., \& Çelik, S. (2018). The effect of boric acid and borax on oxidative stress, inflammation, ER stress and apoptosis in cisplatin toxication and nephrotoxicity developing as a result of toxication. Inflammation. 41(3), 1032-1048. DOI: 10.1007/s10753-018-0756-0

Helvacı, C. (2003). Türkiye borat yatakları jeolojik konumu, ekonomik önemi ve bor politikası. Balıkesir Üniversitesi Fen Bilimleri Enstitüsü Dergisi, 5(1), 4-41.

Hunt, C. D., Herbel, J. L. \& Idso, J.P. (1993). Dietary boron modifies the effects of execise training on bone and energy substrate metabolism in the rat. FASEB J., 7(3), 204.

Hunt, D.C. (1998). Regulation of enzymatic activity, one possible role of dietary boron in higher animals and humans. Biol Trace Elem Res., 66, 205-225.

Ince, S., Kucukkurt, I., Acaroz, U., Arslan-Acaroz, D., \& Varol, N. (2019). Boron ameliorates arsenic-induced DNA damage, proinflammatory cytokine gene expressions, oxidant/antioxidant status, and biochemical parameters in rats. Journal of Biochemical and Molecular Toxicology, 33(2), e22252. Doi.org/10.1002/jbt.22252

Ince, S., Kucukkurt, I., Cigerci, I.H., Fidan, A.F., \& Eryavuz, A. (2010). The effects of dietary boric acid and borax supplementation on lipid peroxidation, antioxidant activity, and DNA damage in rats. J Trace Elem Med Biol. 24,161-4. https://doi.org/10.1016/j.jtemb.2010.01.003

Jasna, J.M., Anandbabu, K., Bharathi, S.R., \& Angayarkanni, N. (2014). Paraoxonase enzyme protects retinal pigment epithelium from chlorpyrifos insult. PLOS ONE. 9(6): e101380.

https://doi.org/10.1371/journal.pone.0101380

Jin, E., Ren, M., Liu, W., Liang, S., Hu, Q., Gu, Y., \& Li, S. (2017). Effect of boron on thymic cytokine expression, hormone secretion, antioxidant functions, cell proliferation, and apoptosis potential via the extracellular signal-regulated kinases 1 and 2 signaling pathway. Journal of agricultural and food chemistry, 65(51), 11280-11291. Doi: 10.1021/acs.jafc.7b04069

Khaliq, H., Jing, W., Ke, X., Ke-Li, Y., Peng-Peng, S., Cui, L., WeiWei, Q., Zhixin, L., Hua-Zhen, L., Hui, S., Ju-Ming, Z., \& KeMei, P. (2018). Boron affects the development of the kidney through modulation of apoptosis, antioxidant capacity, and nrf2 pathway in the African ostrich chicks. Biol Trace Elem Res.186,226-237. https://doi.org/10.1007/s12011-018-1280-7

Kızılca, M., \& Copur, M. (2015). Kinetic investigation of reaction between colemanite ore and methanol. Chemical Engineering Communications., 202(11), 15281534. https://doi.org/10.1080/00986445.2014.956739

Küçükkurt, i., Acaröz, D.A., Demirel, H. H., İnce, S., \& Eryavuz, A. (2017). Potential protective effect of boron against gentamicin-induced oxidative stress on rat tissues. Kocatepe Veteriner Dergisi, 10(3), 172-179. Doi: $10.5578 / \mathrm{kvj} .57557$

Liu, Y., Wang, J., Wei, Y., Zhang, H., Xu, M., \& Dai, J. (2008). Induction of time-dependent oxidative stress and related transcriptional effects of perfluorododecanoic acid in zebrafish liver. Aquatic Toxicology, 89(4), 242250. Doi: 10.1016/j.aquatox.2008.07.009

Mohora, M., Boghianu, L., Muscurel, C., Dute, C., \& Dumitrache, C. (2002). Effect of boric acid redox status in the rat livers. Rom J Biophys. 12(3-4), 77-82.

Nielsen, F.H. (1994). Biochemical and physiologic consequences of boron deprivation in humans. Environ Health Perspect, 102,59-63.

https://doi.org/10.1289/ehp.94102s759

Niki, E., Yoshida, Y., Saito, Y., \& Noguchi, N. (2005). Lipid peroxidation: mechanisms, inhibition, and biological effects. Biochem Biophys Res Commun 338, 668-676. https://doi.org/10.1016/j.bbrc.2005.08.072

Ozdulger, A., Cinel, I., Koksel, O., Cinel, L., Avlan, D., Unlu, A., Okcu, H., Dikmengil, M., \& Oral, U. (2003). The protective effect of $\mathrm{N}$-acetylcysteine on apoptotic lung injury in cecal ligation and puncture-induced sepsis model. Shock. 19(4), 366-72.

Parlak, V. (2018). Evaluation of apoptosis, oxidative stress responses, AChE activity and body malformations in zebrafish (Danio rerio) embryos exposed to deltamethrin. Chemosphere. 207, 397-403. https://doi.org/10.1016/j.chemosphere.2018.05.112

Pawa, S., \& Ali, S. (2006). Boron ameliorates fulminant hepatic failure by counteracting the changes associated with the oxidative stress. Chem Biol Interact, 160(2), 89-98. Doi: 10.1016/j.cbi.2005.12.002

Price, T.A., Uras, F., Banks, W.A., \& Ercal, N. (2006). A novel antioxidant $\mathrm{N}$-acetylcysteine amide prevents gp120-and Tat-induced oxidative stress in brain endothelial cells. Experimental Neurology, 201,193-202.

https://doi.org/10.1016/j.expneurol.2006.03.030

Rahman, K. (2007). Studies on free radicals, antioxidants, and co-factors. Clinical interventions in aging. 2(2), 219.

Rowe, R.I., Bouzan, C., Nabili, S., \& Eckhert, C.D. (1998). The response of trout and zebrafish embryos to low and high boron concentrations is U-shaped. Biological Trace Element Research. 66(1-3), 261-270.

Sugino, N., Karube-Harada, A., Sakata, A., Takiguchi, S., \& Kato, H. (2002). Nuclear factor-KB is required for tumor necrosis factor- $\alpha$-induced manganese superoxide dismutase expression in human endometrial stromal cells. The Journal of Clinical Endocrinology \& Metabolism. 87(8), 3845-3850. https://doi.org/10.1210/jcem.87.8.8771

Sun, Y., Oberley, L.W., \& Li, Y. (1988). A simple method for clinical assay of superoxide dismutase. Clinical Chemistry. 34(3), 497-500.

Turkez, H. (2008). Effects of boric acid and borax on titanium dioxide genotoxicity. J Appl Toxicol. 28, 658-64. https://doi.org/10.1002/jat.1318

Turkez, H., Geyikoglu, F., \& Colak, S. (2011). The protective effect of boric acid on aluminum-induced hepatotoxicity and genotoxicity in rats. Turkish Journal of Biology. 35(3), 293-301. doi:10.3906/biy-0902-11

Turkez, H., Geyikoğlu, F., Tatar, A., Keleş, S., \& Özkan, A. (2007). Effects of some boron compounds on peripheral human blood. Zeitschrift für Naturforschung C, 62(11-12), 889896. https://doi.org/10.1515/znc-2007-11-1218

Turkez, H., Tatar, A., Hacimuftuoglu, A., \& Ozdemir, E. (2010). Boric acid as a protector against paclitaxel genotoxicity. Acta Biochim Pol. 57,95-7.

Verbitskaya, G. V. (1975). Experimental and field investigations concerning the hygienic evaluation of boron-containing 
drinking water. Gigiena i Sanitariya, 7, 49-53.

Yan, S., Wang, J., Zhu, L., Chen, A., \& Wang, J. (2015). Toxic effects of nitenpyram on antioxidant enzyme system and DNA in zebrafish (Danio rerio) livers. Ecotoxicology and Environmental Safety, 122, 54-60.

https://doi.org/10.016/j.ecoenv.2015.06.030
Yazıcı, S., Aksit, H., Korkut, O., Sunay, B., \& Çelik, T. (2014). Effects of boric acid and 2-aminoethoxydiphenyl borate on necrotizing enterocolitis. Gastroenterology, 58(1), 61-67.

https://doi.org/10.1097/MPG.0b013e3182a7e02b 